\title{
Psychological Capital and Career Outcomes among Final Year University Students: the Mediating Role of Career Engagement and Perceived Employability
}

\author{
Martin Mabunda Baluku ${ }^{1,2}$ (D) Eriphase Nsaale Mugabi ${ }^{1} \cdot$ Joyce Nansamba $^{1}$ • \\ Leonsio Matagi ${ }^{1} \cdot$ Peter Onderi $^{3} \cdot$ Kathleen Otto $^{2}$
}

Accepted: 13 May 2020 / Published online: 25 May 2020

(C) The Author(s) 2020

\begin{abstract}
Increasingly, graduates are taking much more time in the transition from school to work. Recent research suggests that the ability to adjust quickly plays a key role in the transition process. This is even more important today given the tough labor market realities such as exacerbated unemployment levels and global competitions for the few available job openings. Yet new graduates often lack experience and certain skills that employers look for. Those unable to maneuver through the School-To-Work Transition (STWT) quickly may experience further challenges in their career development process. Using a sample of 516 students in their final semester of their university studies in Ugandan and Kenya, the present study examines the role of psychological resources, namely psychological capital and the mechanisms (i.e. Career Engagement - CE, Perceived Employability - PE) through which it works to affect students' readiness for STWT as well as positively evaluating their career success. The major findings of the study reveal substantial positive direct effects of psychological capital on perceived employability, readiness for STWT, and career satisfaction. The double mediation results show that psychological capital indirectly affects the readiness for STWT via career engagement and internal PE, while psychological capital indirectly affects career satisfaction via career engagement and external PE. The implications of these results are discussed.
\end{abstract}

Keywords Career engagement - Intrinsic career satisfaction · Perceived employability · Psychological capital · School-to-work transition · Social cognitive model of career selfmanagement

Martin Mabunda Baluku

mbaluku@ chuss.mak.ac.ug; mbaluku1@gmail.com; martin.baluku@staff.uni-marburg.de

Extended author information available on the last page of the article 


\section{Introduction}

A successful and satisfying career life is a goal for everyone involved in work. For those prospecting to enter the world of work, how fast one succeeds in finding work is essential to career progression. Hence, employability and school to work transition (STWT) are very important concerns for young people seeking to enter professional career life. But they are also important for economies in ensuring a sustained productive labor force (Sharland et al. 2013).

STWT is increasingly becoming prolonged and stressful resulting from the different factors that have made the labor market arduous to navigate. Particularly, growing joblessness and underemployment are challenges for both developed and less developed countries (Dietrich and Möller 2016). The world is experiencing slowed economic development as well as growing unemployment resulting from economic crises and health pandemics (Abel et al. 2014; Khan and Faisal 2020; Ruiz Estrada et al. 2020). This is in addition to the population boom and growing urbanization in Africa (Awiti and Scott 2016; Gerland et al. 2014; Sulemana et al. 2019). All these imply that the labor market is increasingly crowded; hence successful entry into the labor market is quite difficult even for the highly skilled and talented individuals.

The challenge is even greater for first-time labor market entrants, most especially recent college or university graduates (Hanapi and Nordin 2014; Nathan and Scobell 2012), significantly deteriorating the quality of STWT. Therefore, this indicates an increasing distance that young people have to traverse from graduation to obtaining the first meaningful job. An important concern in this regard is the reduced skill level and quality among new graduates (Hanapi and Nordin 2014) that often do not meet the standards employers require. This is in addition to changing career and employment relations (Forrier et al. 2015), specifically in the growing service economy (Dall'erba et al. 2009; Gohmann et al. 2008) and the emphasis on protean careers (De Vos and Soens 2008; Hall 1996; Inkson 2006). Whereas these provide challenges such that there are limited organizational jobs, they also provide opportunities for individuals who have resources to self-determinedly take control of their career progress. For example, growth in the service industry provides entrepreneurial opportunities; hence chances of reducing the length of the STWT period exist.

Therefore, the main challenge this study addresses is that young people are increasingly experiencing lengthy STWT (Koen et al. 2012; Sortheix et al. 2015). The challenges in the labor market described above are leading many young individuals into floundering tendencies (Konstam 2015; Vuolo et al. 2014), which is further associated with stunted career development (Konstam 2015; Krahn et al. 2015). Some are at risk of never getting employment in their prime youthful years, despite spending several years in school. Previous research has attributed these challenges to educational factors including the orientation of education systems, the level of educational attainment, and the nature of qualifications (e.g. Ling and O'Brien 2013; Quintini and Martin 2014; Weiss 2014). Other influences relate to socioeconomic status (Blustein et al. 2002; Vuolo et al. 2014), low human capital of youths - particularly the lack of experience (Pastore 2015) and the changing labor market conditions (Vuolo et al. 2011; Weiss 2014). However, the focus on protean careers and self-management (Hall 1996, 2002; Lent et al. 2016; Lent and Brown 2013) implies that individuals have the capacity to deal with these situations to ensure continuity in their career 
development calling for the demand to focus on personal, particularly the psychological, factors.

Studies on psychological factors that are important for STWT have focused on personality and values (e.g. Baay et al. 2014; Vuolo et al. 2014), motivation and self-efficacy (e.g. Heckhausen et al. 2013) and perceptions of job opportunities (Reeskens and Oorschot 2012). We seek to extend this discussion by proposing that students have resources, summated in the concept of psychological capital (Goldsmith et al. 1997; Luthans et al. 2004), that they can use to get ready for STWT. Psychological capital is constituted by resources that depict a positive mindset that is necessary to succeed in career-related activities (e.g. Baluku et al. 2018). Whereas psychological capital can be strengthened by mastery and vicarious experiences (Luthans et al. 2004; Luthans and Youssef-Morgan 2017) during the education process; individuals with high psychological capital are most likely to be engaged in their study because of its effect on vocational motivation and attitudes (Datu et al. 2016; Simons and Buitendach 2013).

This study examines the interlinkages through which psychological strengths can be used to foster young people's adjustment to STWT. To shorten the transition period and reduce the stress associated with joblessness after graduation, students need to be ready for the process long before graduation. The Social Cognitive Model of Career Self-Management (Lent and Brown 2013) proposes a framework through which individuals can adopt and take charge of such transitions and achieve career success. We use this framework to demonstrate that psychological capital enhances career engagement among students which in turn is related to higher perceived employability and through this mechanism enhances the readiness for STWT and career satisfaction. To test these assumptions, we look at a sample of East African (Uganda and Kenya) university students who are nearing graduation.

\section{Theoretical Framework}

The main proposition of this paper is that psychological resources, particularly psychological capital, are necessary for prospecting graduates to prepare themselves for the arduous STWT task. This argument derives from the Social Cognitive Model of Career Self-Management (Lent and Brown 2013). The Social Cognitive Model of Career SelfManagement (SCM-CSM) is an extension of the Social Cognitive Career Theory - SCCT (Lent et al. 1994), adding the micro-level processes that address the question of how people handle predictable and less predictable career development tasks (Lent et al. 2016; Lent and Brown 2013). The process aspects that the model explains include, for example, mechanisms involved in making career decisions, career transitions and finding work (Lent et al. 2016).

The present study contributes to scholarly efforts in extending the application of the model to the readiness for STWT transition; and specifically to students in less developed East African countries in the context of high youth unemployment. We posit that early readiness and adjustment to STWT is one of the adaptive behaviors, the model seeks to explain, that students can engage in to achieve success in the labor market. The model particularly emphasizes cognitive variables including self-efficacy, outcome expectations, goals, as well as actions (Lent et al. 2016; Lent and Brown 2013), which actually depict the role of psychological capital facets of self-efficacy or confidence, optimism, hope (relates to formulation of goals and strategies to achieve them), as well as resilience (concerns persistence in 
actions in the process of pursuing goals) (Luthans et al. 2004, 2015; Luthans and YoussefMorgan 2017).

However, the SCM-CSM hypothesizes a process, whereby self-efficacy and outcome expectations facilitate goals and actions (Lent et al. 2016). Analogized with the constructs of the present study, this assumption indicates that psychological capital facilitates career actions (career engagement) and goals (employability, STWT, and success). In line with the emphasis of adaptability and career self-management, the attributes similar to resources that constitute psychological capital are linked to career engagement behaviors and employability (Coetzee and Schreuder 2017) as well as job search intentions and behaviors (Lim et al. 2016); suggesting that such resources are also important for STWT and career satisfaction. The next paragraphs explain these career outcomes in the context of the present study.

\section{Literature Review and Hypotheses}

\subsection{School-to-Work-Transition (STWT)}

STWT is conceived as a systematic course of moving from full-time school involvement to fulltime engagement in work (Ryan 2001; Vuolo et al. 2014). The process involves leaving school, then developing a professional identity, job search (entering the labor market), and consequently finding a suitable and stable employment (Akkermans et al. 2015; Quintini and Martin 2014; Ryan 2001). This process tends to take a long period and is stressful due to uncertainty (Ryan 2001), thus requires employing a set of psychological resources to adjust (Heppner 1998; Heppner et al., 1994).

STWT is an important developmental task, such that successful completion of this task may be indicative of higher chances of further career development (Pinquart et al. 2003). However, this task is much affected by individual characteristics and requires readiness, adjustment, and adaptability as is the case with most career development tasks (Krumboltz and Worthington 1999; Tomasik et al. 2009). The first step in readiness is the educational preparation, which occurs during the course of study at college or university. Additional tasks may be relevant in the process of getting ready for the STWT, for instance, planning, scanning for opportunities, and obtaining support. Several factors in addition to individual characteristics, particularly social, economic and vocational factors and their interaction to explain career transitions (Hanapi and Nordin 2014; Krumboltz and Worthington 1999; Lent and Brown 2013) might play a role. It has been suggested, hence, that a better understanding of STWT can be achieved with specific attention paid to each of these factors. The present study is predominantly focused on the psychological processes that enable prospecting graduates to get ready for the transition; which is in line with earlier research indicating that psychological attributes influence one's adaptation in career transition processes (Vuolo et al. 2011). Particularly, we presume that students with strong psychological resources are more likely to transit faster, despite the contextual challenges outlined above.

\subsection{Career Satisfaction}

Concerning career satisfaction, most researchers tend to agree with the classification of career success into intrinsic and extrinsic dimensions (Arthur et al. 2005; Heslin 2005). 
The extrinsic dimension is considered objective because it can be empirically observed through verifiable indicators such as promotions, pay, and status (Heslin 2005; Sturges 1999). These may hardily apply to students still engaged in full-time learning. We therefore specifically concentrate on observing students' intrinsic career satisfaction. Intrinsic career satisfaction is rather subjective since it is based on a person's perception of his or her vocational development, experiences and anticipated career achievements (Heslin 2005). In the context of the present study, intrinsic career satisfaction may arise from perceived employability (De Vos et al. 2011; De Vos and Soens 2008) which we also presume to be linked to the level of one's career engagement and psychological resources. We, therefore, propose that the process through which psychological resources relate to STWT among prospecting graduates is the same process through which they relate to career satisfaction.

\subsection{Psychological Capital and Career Outcomes}

Psychological capital is a state of mind that consists of positive psychological strengths (Avey et al. 2011), hence describes an individual's psychological capacities (Newman et al. 2014) that lead to a positive assessment of circumstances and likelihood of succeeding in a given situation. The appraisal of circumstances and chances of success are, however, based on motivated effort and perseverance (Luthans et al. 2007a, 2007b). Psychological capital (summarized as "who you are") is related but different from human capital (what you know) and social capital (who you know), and is beyond what an individual has (economic capital) (Luthans et al. 2014; Luthans et al. 2004). Although psychological capital has been applied to different aspects of human development and behavior; it is mainly an application of positive psychology to occupational behavior, focusing on what is good rather than what is wrong with individuals or highlighting strengths rather than weaknesses (Luthans et al. 2004; Luthans and Youssef-Morgan 2017); in sum emphasizing the positive attributes that individuals bring to their work and personal development.

Psychological capital is considered a higher order construct comprising of the four aspects self-efficacy, hope, optimism and resilience (Luthans 2012; Luthans et al. 2004; Luthans et al. 2006a, 2006b). Although other concepts from positive psychology have been proposed for inclusion as facets of psychological capital, for example, trust (Page and Donohue 2004); it has been maintained that psychological capital consists of psychological resources that are state-like rather than trait-like and therefore can be developed through specific interventions such as training (Luthans 2012; Luthans and Youssef-Morgan 2017; Newman et al. 2014).

Among the psychological capital dimensions, self-efficacy has been identified in several studies as having a great impact on STWT processes and outcomes. Selfefficacy refers to the belief in one's own capabilities to successfully act in a given situation (Bandura 1995). STWT is one of the situations that require higher levels of self-efficacy beliefs given that it is a developmental process that involves change and uncertainty (Ryan 2001). Indeed, self-efficacy has been found to be important in managing change situations (Vardaman et al. 2012) and particularly useful in adjusting during career transitions (Morton et al. 2014). In the SGM-CSM, self-efficacy is posited to be one of the essential proximal antecedents of adjustment behaviors. The model particularly emphasizes process efficacy implying "perceived ability to manage 
specific tasks necessary for career preparation, entry, adjustment or change"; and coping efficacy, which is the individual's perception of one's own ability to overcome challenges (Lent and Brown 2013). These forms of self-efficacy are highlighted as useful in making career decisions, and career adoptive behaviors (Guan et al. 2016), which not only help in managing STWT, but also can be seen as a precedent of success in the transition period and general career success. Recent empirical research findings support these propositions. For example, self-efficacy has been found to mediate the relationship between some personality factors and career outcomes (Hirschi and Jaensch 2015). Self-efficacy also plays a critical role in regulating one's behavior, taking control of the change process, adjusting to the transition and searching for jobs (Guan et al. 2013; Morton et al. 2014), which reduces the stress of undertaking the transition. STWT is therefore likely to be easier, completed earlier and more successful for individuals with high self-efficacy. This also indicates that individuals with high self-efficacy are more likely to engage and persist in actions that enhance career success, including satisfaction as a subjective measure. Hence self-efficacy is a good predictor of career success (Smidt et al. 2017).

The SGM-CSM underscores outcome expectations, which essentially indicate the role of optimism, as an antecedent for career adaptive career behaviors (Lent and Brown 2013) as well as persistence and satisfaction (Lent et al. 2013). Particularly, optimism tends to relate to subjective career success and marketability (Spurk et al. 2015). Optimism denotes a state in which a person is confident of positive outcomes now or in the future (Carver et al. 2010; Luthans et al. 2007a, 2007b). The expectancy for positive results motivates individuals to act, regulate themselves as well as be committed and resilient (Peterson 2000; Trevelyan 2008); optimism thus is an important attribute for engaging and succeeding in difficult tasks. Within one's career, making decisions to engage in a career transition and the ability to undertake transition processes may be hugely dependent on expected results (Lent and Brown 2013). In addition, optimistic individuals adopt better and report less stress resulting from a career transition (Morton et al. 2014).

There is quite scanty evidence on the role of the remaining psychological capital dimensions of hope and resilience in career transitions and satisfaction. Hope is the perception that one can achieve his/her goals, which motivates the development of pathways and persistence towards achieving the set goals or desired outcome (Luthans and Jensen 2002; Luthans et al. 2007a, 2007b). Positive psychologists posit that hope is derived from way power (ability to develop plans and alternatives to achieve goals) and willpower/ agency (determination to act and maintain effort) and these complement each other in the pursuit of goals (Luthans and Jensen 2002; Luthans 2012; Luthans et al. 2008). Previous research has found hope to be a useful construct in career processes and outcomes such as career exploration, career self-efficacy, and motivation (Hirschi 2014; Valero et al. 2015). Hope is also a cognitive resource that facilitates emotional wellness (Munoz et al. 2016). Moreover, being engaged in developing and pursuing goals enhances career outcomes, such as increased chances of successful job search (Körner et al. 2015) which eventually may translate into success in the STWT as well as perceiving career satisfaction.

Similarly, resiliency can be an important antecedent of achieving positive results in the STWT and for career success. Resiliency is the ability to cope with change (both positive and negative change) and setbacks (Brandt et al. 2011; Luthans et al. 2006a, 
2006b; Masten and Reed 2002). Resiliency enables individuals to continue functioning normally when faced with challenging situations because it tends to restore confidence, hope, and optimism (Luthans et al. 2006a, 2006b). It is, therefore, a resource that individuals need not only when faced with adversity but also when they need to adjust, for instance, in life transitions (Masten et al. 2004). Hence resiliency is important for people to adjust and persist in the STWT process. This ability is also essential for persistence in career activities and could be, therefore, an important contributor to career success. For instance, it has been found that higher levels of resiliency are correlated to more success in the academic career (Hollenbeck and Mannor 2007).

Overall, and beyond merely being an acronym for the four resources, psychological capital has been referred to as the "HERO within" (Luthans and Avolio 2014; Luthans 2012; Luthans and Youssef-Morgan 2017) denoting the positive outcomes for work and career, or other developmental tasks individuals achieve when they possess high levels of psychological capital. It is particularly a resource for dealing with difficult tasks and situations and explains why some people succeed in tough tasks and situations (Baron et al. 2016). With regard to the STWT and career success, however, only self-efficacy has been widely studied. There are hardly any studies that focused on the role of hope, optimism, and resiliency in the STWT process. Our study, therefore, contributes to the application of the concept of psychological capital, beyond selfefficacy in fostering career transitions and success; and we hypothesize that:

H1. Psychological capital will positively predict (a) the readiness for STWT, and (b) career satisfaction.

\subsection{The Role of Career Engagement}

Engagement is a popular occupational resource that represents how employees relate to the organization or work (Bakker and Schaufeli 2014; Schaufeli and Bakker 2000). From the educational perspective, engagement is predominantly used in discussing how students are involved in their learning process (Axelson and Flick 2010) and therefore important in predicting learning and academic success (Fredricks et al. 2016). Moreover, it could be an important target for interventions, given its relationship with work, career or learning outcomes; but also given that it is malleable to relationships, practices, and contexts (Fredricks et al. 2016; Kahu and Nelson 2017). However, we specifically focus on career engagement of students. This is quite different from student engagement. So far, it is described as the proactive development of one's career through diverse career behaviors, specifically being involved in various career management behaviors (Hirschi et al. 2014). In all forms of engagement, the involvement that is referred to comprises of vigor and dedication (that is a high level of effort), absorption in, and identification with the job or profession or task (Bakker et al. 2009; Salmela-Aro and Upadaya 2012). An important observation is that career engagement translates into employee engagement (Neault and Pickerell 2011) indicating that high level of career engagement may relate to other forms of engagement; such as engagement in study activities as well us during career transitions.

Engagement is further characterized by mental resilience, enthusiasm, inspiration, and pride as well as concentration (Upadyaya and Salmela-Aro 2015) on the tasks. 
These could be dependent on the level of psychological capital dimensions of selfefficacy and resiliency and hence be antecedents of career success. Consequently, career engagement is related to career satisfaction (Hirschi and Jaensch 2015; Upadyaya and Salmela-Aro 2015). Career engagement can denote increased involvement in one's own career decisions, planning and enhancing employability skills. Engagement also includes exploring opportunities, networking, which increases the chances of seizing career opportunities (Hirschi 2010) thereby making the STWT transition faster and more successful. Ford et al. (2009) proposed an early engagement hypothesis, suggesting that individuals who are highly and deliberately engaged in specific activities related to their career development tend to be more successful compared to their less engaged counterparts. Results from similar studies, for instance (Fredricks et al. 2016; Hirschi et al. 2011) support this hypothesis by showing that career engagement at an early age is related to career outcomes at later stages. Therefore, engagement in addition to aiding career adaptability and development is also essential for career success. We propose that such success is not only objectively evaluated but also reflected in terms of satisfaction.

Extant literature on career engagement largely portrays career engagement to mediate the effects of personal factors such as personality and cognitive abilities on career outcomes (Hirschi and Jaensch 2015; Le et al. 2016). Regarding psychological capital, research on its individual facets shows self-efficacy particularly increases students' engagement in career-related activities (Caraway et al. 2003). Moreover, career engagement involves employing one's efficacy resources (Hirschi et al. 2013; Kim et al. 2014). In addition, engagement transmits the effects of optimism on career adaptation; whereby engagement represents the adaptation process (Perera and McIlveen 2014). This implies that engagement represents the application of one's psychological strengths to career development activities; hence engagement should result into superior career outcomes. We therefore hypothesize that:

- Hypothesis 2: Career engagement will be positively related to (a) the readiness for STWT and to (b) career satisfaction.

\subsection{Perceived Employability as an Outcome and Mediator}

Entering the labor market implies that an individual has some sellable goods (competences) that the buyers (employers) are seeking. The employability concept is more important now than ever for new entrants in the labor market, given that the labor market is rapidly evolving amidst challenges such as growing unemployment, job insecurity, globalization, and mechanization of workplaces. These have implications of the kind of work that is available, where and the skill sets needed. These realities have necessitated that careers also become more dynamic requiring more protean behaviors (Forrier and Sels 2003; Hall 2002; Lo Presti and Pluviano 2015) to compete for available employment opportunities. Whereas employers may be interested in the objective employability, subjectively perceived employability may be important in assessing one's own ability to compete in the labor market. We, therefore, assess whether perceived employability has an effect on a person's adjustment to STWT as well as on career satisfaction. Perceived employability is the evaluation of a person's 
chances of finding a job (Cuyper et al. 2015; Forrier et al. 2015) as well as the ability for sustained employment (Berntson and Marklund 2007; Vanhercke et al. 2014). It is, therefore, more subjective in nature (Vanhercke et al. 2014). The study of perceived employability is important because individuals' behavior in the labor market is likely to be guided by their perceptions (De Cuyper et al. 2015; Kirves et al. 2014) rather than the objective aspects of employability. Whereas objective employability is what matters for employers, the actions taken by prospecting employees largely depends on their perceived abilities and contexts.

Rothwell, Herbert, and Rothwell (2008) categorized perceived employability into two aspects; an internal aspect (appraisal of one's own academic performance, skills and abilities to get a job) and an external aspect (evaluation of external factors such as labor market conditions, strength of the university's brand and demand of the subject area). Internal perceived employability emphasizes the personal psychological attributes, such as vocational efficacy, based on the assumption that these are proximal to a person's actions (Forrier et al. 2015; Praskova et al. 2014; Rothwell et al. 2008; Vanhercke et al. 2014). They again are reflected in individuals' perceptions of their skills and abilities, academic performance, ambition, and awareness of opportunities which are clustered as self-confidence and proactivity (Rothwell et al. 2008, 2009). The external aspect highlights the perceptions about the labor market and available opportunities (Forrier et al. 2015; Praskova et al. 2014). This includes perceptions about the reputation of a university, fields of study, and the demand of the profession in the labor market (Rothwell et al. 2008).

In line with the SGM-CSM, employability encompasses notions of career identity, self-management, professional development, networking, and environmental monitoring (Forrier et al. 2015; Forrier and Sels 2003; Fugate et al. 2004). In terms of outcomes, perceived employability results in job search behaviors and career success (Dacre Pool and Qualter 2013; De Vos and Soens 2008; Lo Presti and Pluviano 2015). Moreover, job search behaviors are important for career transitions, particularly in the process of finding a job (Forrier et al. 2015). In addition, perceived employability has been found to increase adaptability to alternative opportunities, for example, employment in the private sector (Forstenlechner et al. 2014), which may increase chances of successful and fast STWT.

Previous research has also investigated the predictors or sources of perceived employability. Similar to constitutes of perceived employability (Rothwell et al. 2008, 2009; Vanhercke et al. 2014); it has been found to be determined by personal and social or contextual factors. The context - including the level of career development support and labor market dynamics - is important to form perceptions of one's ability to obtain and or maintain a job (Donald et al. 2017; Wittekind et al. 2010). Among personal factors, psychological and human capital are particularly emphasized. Human capital consists of education level, expertise, academic performance, skill level and experience (Donald et al. 2017; Jackson and Wilton 2017; Rothwell et al. 2008; Van Der Heijde and Van Der Heijden 2006; Wittekind et al. 2010). The literature, though, is increasingly focusing on individuals' psychological attributes and resources. Competencies such as flexibility, adaptability, and career self-management (Clarke 2017; Jackson and Wilton 2017; Van Der Heijde and Van Der Heijden 2006) are seen as central for developing a sense of employability; this being also in line with protean abilities deemed necessary for career development in the contemporary work environment. The application of psychological resources to the development of 
perceived employability is still limited. However, perceived employability itself is conceptualized to revolve around efficacious perceptions of chances to succeed in the labor market (Forrier et al. 2015; Kasler et al. 2017; Praskova et al. 2014; Rothwell et al. 2008); suggesting that psychological capital could be essential for enhancing perceived employability. This is also highlighted in the findings of Chen and Lim (2012) and other studies associating psychological capital to success in job search behavior. For instance, the hope dimension of psychological capital, which includes the ability to develop and work towards achieving goals, enhances perceived employability (Kasler et al. 2017).

Overall, the above literature leads us to the assumption that psychological capital is associated with perceived employability which itself predicts career outcomes of adjustment to transition and career success. In the previous sections, we have further explained that these career outcomes and psychological capital are associated with career engagement, such that career engagement mediates the positive effects of psychological capital on the readiness for STWT and perceived career satisfaction. The increased emphasis on careerself management indicates the essentiality of career engagement in the realization of career outcomes including employability, as well as managing transitions and career success (Lent and Brown 2013). We therefore posit that students who possess high levels of psychological capital are likely to be more engaged in their career development process which enhances perceived employability, adjustment to STWT, and career success. This suggests a double mediation model whereby the positive effects of psychological capital on the readiness for STWT are transmitted through career engagement and perceived employability.

- Hypothesis 3: Perceived employability will be positively related to (a) the readiness for STWT and (b) career satisfaction.

- Hypothesis 4: There will be a double mediation such that psychological capital will have positive effects on (a) the readiness for STWT and on (b) career satisfaction via career engagement and perceived employability.

\section{Methods}

\subsection{Procedure and Participants}

The study was conducted at three universities in East Africa (Uganda and Kenya). University students in the final year of their studies were approached, as they are facing STWT as their next career development challenge. Questionnaires were administered to participants in their lecture/ seminar rooms with the help of their tutors/ lecturers. Hence the sample was selected using a convenient method. However, participation was completely voluntary and no incentives were provided to participants.

The sample comprised of 516 bachelor degree students; 299 Ugandan (58.53 female and $41.47 \%$ male) and 217 Kenyan (53\% female and $47 \%$ male). The participants were relatively young with their ages ranging from 18 to 30 years $(\mathrm{M}=23.02$ years, $\mathrm{SD}=6.12)$. Participants were drawn from different professions in the following general areas: Humanities and social sciences $(53.5 \%)$, teacher 
training $(29.1 \%)$, natural and health sciences $(9.1 \%)$, and business and management studies $(8.3 \%)$.

\subsection{Measures}

Positive Psychological Capital The Psychological Capital Questionnaire (PCQ-24) selfrater version (Luthans et al. 2007a, 2007b) was used. The questionnaire consists of 24 items measured on a 6 -point Likert format scale $(1=$ strongly disagree and $6=$ strongly agree). Sample items include: "I feel confident presenting information to a group of colleagues" (efficacy aspect); "I can think of many ways to reach my current career goals" (hope aspect); "I usually take stressful things in my career life in a stride" (resiliency aspect); and "I always look on the bright side of things regarding my career" (optimism aspect). In the present study, the questionnaire had a Cronbach $\alpha$ of .83; which is good considering .70 as the acceptable cutoff alpha value (Nunnally 1978).

Career Engagement This was assessed using the Career Engagement Scale (Hirschi et al. 2014). The 9-item scale asks participants to what extent they have engaged in certain career behaviors/ activities in the preceding six (6) months. A sample item is "......actively sought to design your professional future." Items are measured on a 5point Likert format scale $(1=$ not much, and $5=$ a great deal $)$. The scale has good psychometric properties (Hirschi et al. 2014); and also yielded a good Cronbach $\alpha$ for the present study (.84). It was also validated mainly with university students (in five of the six development and validation studies), therefore, appropriate for the sample of the present study.

Perceived Employability This was operationalized using the Self-Perceived Employability Scale for students (Rothwell et al. 2008). The 16-item scale measures both internal and external perceived employability by assessing a person's perception of the value of his or her personal and occupational attributes in the labor markets. Sample items include: "the skills and abilities I possess are what employers are looking for" (for internal dimension); and "employers specifically target this university in order to recruit individuals from my subject areas" (for external dimension). The items are measured on a 5-point Likert type scale ( $1=$ strongly disagree, and $5=$ strongly agree). The scale showed acceptable reliabilities ( $\alpha=.78$ for external and $\alpha=.83$ for internal).

Intrinsic Career Satisfaction We used the 5-item career satisfaction questionnaire (Greenhaus et al. 1990), which assesses the perceived degree to which people are satisfied in their careers. The items are assessed on a 5-point Likert style scale $(1=$ strongly agree, and $5=$ strongly disagree). A sample item reads like this: "I am satisfied with the progress I have made towards achieving my overall career goals". The scale showed a high reliability for the present study $(\alpha=.95)$.

Readiness for School-to-Work Transition (STWT) We adopted items from the Career Transitions Inventory - CTI (Heppner et al. 1994). The CTI measures career transition adjustment by assessing the psychological resources (readiness, confidence, perceived support, control, and decision independence) used in career transitions. The inventory consists of 40 items assessed on a 6-point Likert format scale (1 strongly agree, and $6=$ 
strongly disagree). For purposes of the present study, only nine (9) items relating to readiness were adopted. Sample items are; "I feel as though I have a driving force within me to work on this career transition right now" and "Each day I do something on this transition process, I would say I'm motivated." The items for readiness adopted for the present study also showed a high reliability $(\alpha=.89)$.

\subsection{Analytical Procedure}

To test our hypotheses, we applied the double mediation analysis using PROCESS macro version 2.16 Model 6 (Hayes 2013). Whereas this analytical tool applies ordinary least squares regression, it is a versatile tool that incorporates repeated computations in form of bootstrapping which is necessary for computation of confidence intervals for indirect effects in simple and multiple mediations (Hayes 2012, 2018). The model concurrently tests for direct and indirect effects. Two models were computed. The first model tested for the direct and indirect effects of psychological capital on readiness for STWT via career engagement and perceived employability (PE) dimensions. The second model tested for the direct and indirect effects of psychological capital on career satisfaction through career engagement and PE dimensions. For confidence interval estimates, we applied bootstrapping at 5000 as described in Hayes $(2013,2018)$.

\section{Results}

The means, standard deviations, and intercorrelations for the study variables are presented in Table 1. Findings relating to all hypotheses are presented in Table 2 and visualized in the empirical model in Fig. 1.

Concerning the control variables, our results reveal that age was not related to any of the mediator and outcome variables. Sex was also only showing a positive relationship to internal PE; implying that female students demonstrate higher internal employability than their male counterparts. Country was found to relate positively to internal PE and readiness for STWT, indicating that Kenyan university students compared to Ugandan

Table 1 Descriptive statistics and correlations

\begin{tabular}{|c|c|c|c|c|c|c|c|c|}
\hline & $M$ & $S D$ & 1 & 2 & 3 & 4 & 5 & 6 \\
\hline 1. Psychological capital & 4.52 & .56 & .83 & & & & & \\
\hline 2. Career engagement & 3.77 & .77 & $.32^{* * * *}$ & .84 & & & & \\
\hline 3. Perceived employability - external & 3.67 & .73 & $.34^{* * *}$ & $.40^{* * * *}$ & .78 & & & \\
\hline 4. Perceived employability - internal & 3.90 & .68 & $.32^{* * *}$ & $.42^{* * *}$ & $.63^{* * *}$ & .83 & & \\
\hline 5. Career satisfaction & 3.48 & .99 & $.21^{* * *}$ & $.25^{* * * *}$ & $.28^{* * * *}$ & $.20^{* * *}$ & .95 & \\
\hline 6. Readiness for STWT & 3.80 & 1.30 & $.25^{* * *}$ & $.21^{* * * *}$ & $.19^{* * * *}$ & $.40^{* * * *}$ & $.15^{* * * *}$ & .89 \\
\hline
\end{tabular}

Notes: $\alpha$ in diagonal bold

$* * * \mathrm{p}<.001, * * \mathrm{p}<.01, * \mathrm{p}<.05$ 


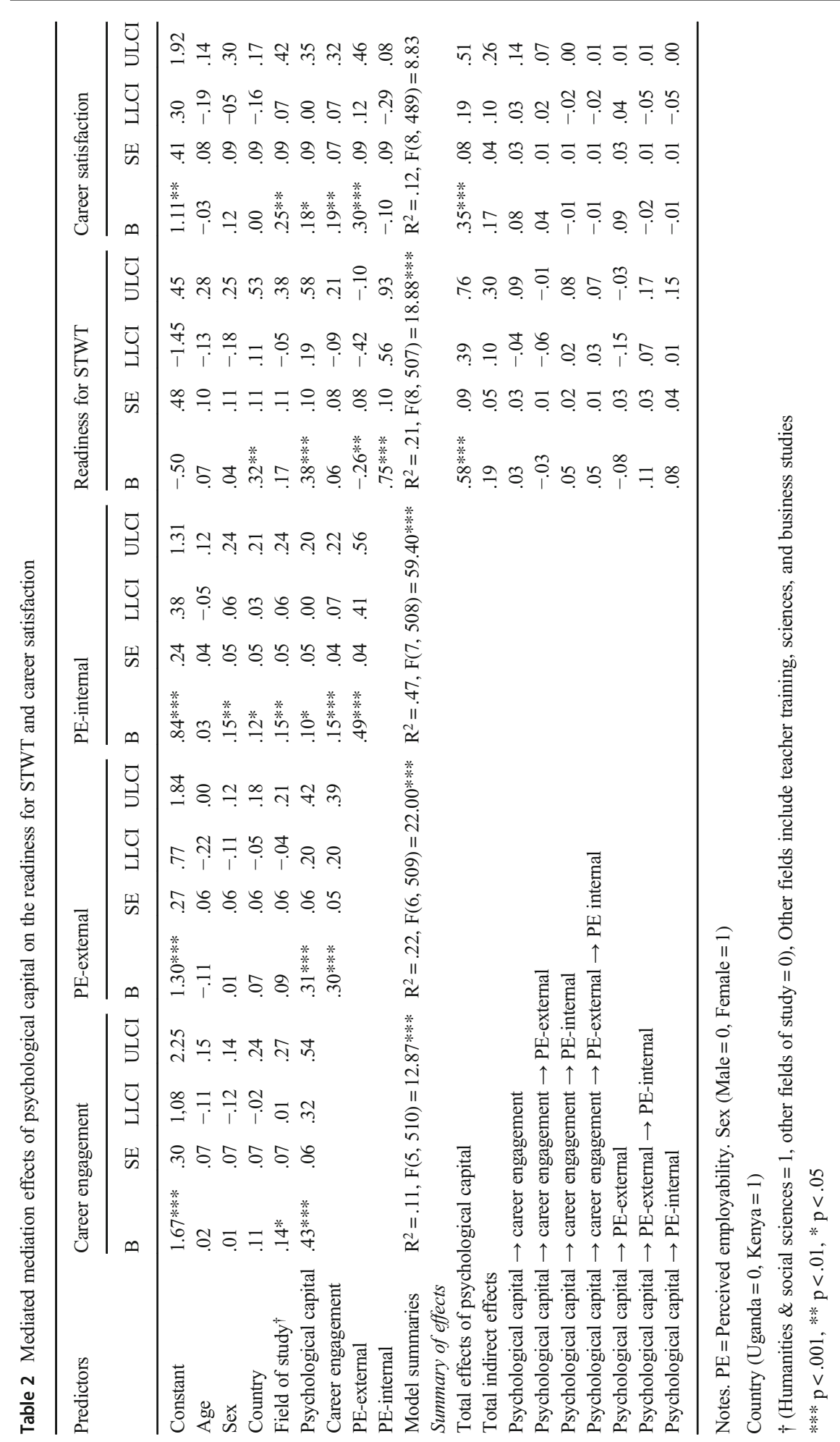




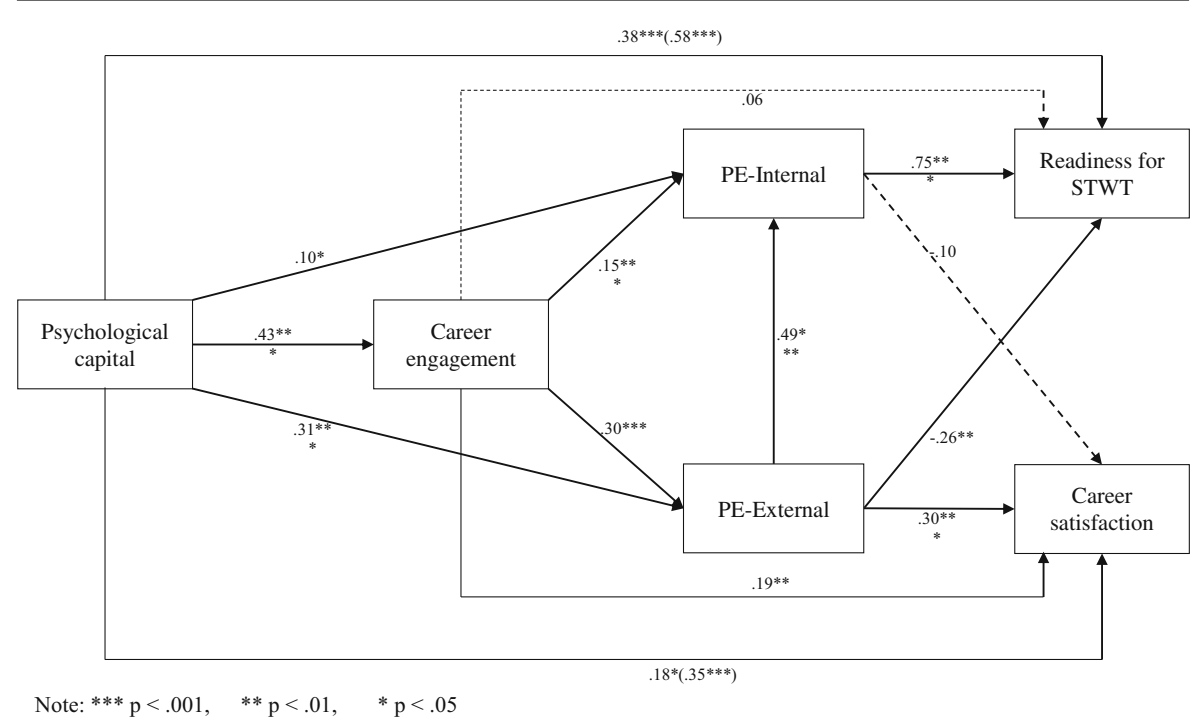

Fig. 1 Conceptual model illustrating direct and indirect effects of psychological capital on the readiness for STWT and career satisfaction via career engagement and perceived employability (total of psychological capital effects indicated in brackets)

university students possess higher internal perceived employability and evaluate themselves to be more ready for STWT. Field of study was positively related to three variables: career engagement, internal perceived employability, and career satisfaction. These results indicate that in this study, students in the courses in the domain of humanities and social sciences reported higher scores on each of these variables.

We hypothesized that psychological capital and the mediator variables (career engagement, PE) are positively related to both outcome variables (readiness for STWT and career satisfaction). Results of our double mediation model in Table 2 show that psychological capital was positively related to both mediator variables and both outcome variables; readiness for STWT $(B=.38, p<.001)$ and career satisfaction $(B=.18, p<.05)$; thus $H 1 a$ and $H 1 b$ are supported. Career engagement also showed positive relations to $\mathrm{PE}$, both external $(B=.30, p<.001)$ and internal $(B=.15$, $p<.001)$, as well as career satisfaction $(B=.19, p<.01)$ but not to the readiness for STWT. These results specifically support $H 2 b$ but not $H 2 a$. Regarding $H 2 a$, however, there was a positive relationship as can be seen in Table 1 . This may imply that the effects of career engagement on the readiness for STWT are fully mediated by PE dimensions as illustrated in Fig. 1.

We further hypothesized that perceived employability (PE) is positively related to both the readiness for STWT and career satisfaction $(H 3 a$ and $H 3 b)$. On the bivariate level, the two PE dimensions showed a different pattern of correlations. We therefore, decided to progress with our main analysis on the facet level (see: Rothwell and Arnold 2007; Rothwell et al. 2008). The external aspect was negatively correlated to the readiness for STWT $(B=-.26, p<.01)$ but positively to career satisfaction $(B=.30$, $p<.001)$. On the other hand, the internal aspect was positively related to the readiness 
for STWT $(B=.75, p<.001)$ but not related to career satisfaction. Moreover, external $\mathrm{PE}$ also had positive effects on internal PE $(B=.49, p<.001)$.

It is implied in hypothesis 4 that the positive effects of students' psychological capital on the readiness for STWT and career satisfaction are mediated by career engagement and PE. The hypothesis particularly suggests a double mediation, such that the effects of psychological capital on the readiness for STWT and career satisfaction are transmitted through career engagement (first mediator) and PE (second mediator). As shown in the summary of effects and confidence intervals (CI) in Table 2, overall, there were significant total indirect effects of psychological capital on the readiness to STWT $(B=.19, C I=.10$ to .30$)$ and career satisfaction $(B=.17$, $C I=.10$ to .26 ).

Regarding the specific indirect effects, our results indicate that psychological capital was indirectly positively related via career engagement to career satisfaction $(B=.08$, $C I=.03$ to .14 ) but not to the readiness to STWT. As suggested above, lack of relationship between career engagement and the readiness for STWT is interpreted to indicate that the effects are fully mediated by the dimensions of PE (see, Fig. 1). Again, as indicated in the previous paragraph, the effects of PE were segregated according to the dimensions. Accordingly, our results show that indirect effects of psychological capital via external PE were positive for the readiness for STWT $(B=.08, C I=.01$ to $.15)$; but not significant for career satisfaction. On the contrary, indirect effects of psychological capital via external PE were negative for the readiness to STWT $(B=$ $-.08, C I=-.15$ to -.03$)$ but positive for career satisfaction $(B=.09, C I=.04$ to .01$)$. Moreover, we found that the indirect effects of psychological capital on the readiness for STWT via external PE are further mediated by internal PE ( $B=.11, C I=.07$ to .17); further implying that although external PE has a negative direct impact on the readiness for STWT, it still enhances internal PE, which consequently leads to improved readiness for STWT. Concerning the double mediation, we found that the path from psychological capital via career engagement and external PE was negative for the readiness for STWT $(B=-.03, C I=-.06$ to -.01$)$ but positive for career satisfaction $(B=.04, C I=.02$ to .07$)$. On the other hand, the double mediation path via internal PE was positive and significant but only for the readiness for STWT $(B=.05, C I=.02$ to .08). Similarly, the path from psychological capital via career engagement, external PE, and internal PE was significantly positive for the readiness to STWT only $(B=.05$, $C I=.03$ to .07$)$ and not for career satisfaction. Overall, these results show partial support for $H 4$.

\section{Discussion}

It has been suggested that psychological capital is the resource needed to achieve superior results in career situations such as work and business and to maintain high level of wellbeing even in stressful circumstances (Baron et al. 2016; Luthans et al. 2007a, 2007b; Luthans et al. 2004; Luthans and YoussefMorgan 2017; Newman et al. 2014). In the present study, we argue that psychological capital is an important resource for students leading to engagement in their career, which in turn improves their perceptions of employability. At the end of this process, a higher readiness for STWT and more perceived 
career satisfaction should be found. This is also in line with the assumptions of SCM-CSM that individuals have the ability to self-determinedly take charge of their career development process (Lent and Brown 2013). The present findings support this assumption; indicating that final year university students with higher psychological capital report (more) positive career outcomes; specifically, they show relatively higher PE (both external and internal), a higher readiness for STWT and higher career satisfaction as compared to their counterparts possessing lower psychological capital.

In the present career environment, entering the labor market is a daunting task that every prospecting university graduate faces. The challenge is even greater in less developed countries, especially in Africa, where the realities of the labor market are quite scaring for those seeking employment. The first reality that these young yet inexperienced new entrants in the labor market are confronted with is the likelihood of unemployment or at best underemployment (Hanapi and Nordin 2014; Koen et al. 2012; Magelah \& Ntambirweki-Karugonjo, 2014; Nathan and Scobell 2012). Therefore, the process of adjusting to STWT is not only stressing, but also likely to take a longer time period (Koen et al. 2012). However, findings of the present study indicate that (at least) some students are ready for STWT long before graduating from their university. This is essential when aiming to shorten the transition period, and therefore, increasing the likelihood of continuous career progression. Such students are likely to find a job or voluntary placement before or immediately after graduation or enroll for further studies. Our results indicate that this process is facilitated by a high level of psychological capital.

Psychological capital comprises of the positive resources of efficacy, hope, resiliency, and optimism (Luthans et al. 2004) which together increase an individual's capacity and motivation to take on, persist, and succeed in challenging tasks (Luthans et al. 2007a, 2007b; Luthans and Youssef-Morgan 2017). This explains why individuals with high psychological capital report a higher readiness for STWT even in the context of unemployment and underemployment. The positive psychological resource of hope is, for example, described in terms of agency and pathways to achieve goals (Snyder 2002; Snyder et al. 1996), thus enabling students to develop alternative pathways negotiating their entry into the labor market. In this regard, students with high psychological capital are able to consider alternatives to the traditional employment paths such as the willingness to work in the private sector or to go into self-employment. The efficacy and optimism resources provide the individual with the motivational confidence and expectation to succeed even when the context is unfavorable or risky. The motivation to persist that accrues from resiliency is also important in the process of preparing for STWT. These abilities not only help a student to get ready for the STWT but also boost career satisfaction.

Over and above shedding light on these linear effects we were also interested in exploring underlying mechanisms. Our results show that psychological capital exerts a significant impact on adjustments to STWT and career satisfaction through career engagement. These results suggest that adjustment to STWT and career satisfaction are determined by similar antecedents, particularly, the positive psychological resources. These resources facilitate a high level of appreciation of one's career progress as well as involvement in decisions and activities that enhance career growth. High levels of vigor, dedication, inspiration and motivation that characterize engagement in 
study and work activities, as well as career decisions (Hirschi et al. 2014; Schaufeli and Bakker 2000; Upadyaya and Salmela-Aro 2015) are partly determined by the individual's amount of psychological capital. Therefore, psychological resources that constitute psychological capital facilitate one's career engagement (e.g., Hirschi et al. 2013; Perera and McIlveen 2014) given that it is related to motivation for and persistence in pursuit of goals. Our findings not only confirm the assumed mediation path from psychological capital to the readiness for STWT and career success but also show support for the early career engagement hypothesis (Ford et al. 2009). Being engaged in one's own career development processes including career decisions, career planning, exploration of opportunities, networking, and undertaking skills enhancement activities among others, increase chances of career success which in the context of this study include successful STWT and career satisfaction. Prospecting graduates who engage in these activities during their time at college are more likely to have an advantage in the job search process or obtain opportunities for further education.

Further investigation of the mechanisms through which psychological capital impacts the readiness for STWT and career satisfaction indicate a double mediation through career engagement and PE. Moreover, the effects of career engagement on the readiness for STWT seem to be fully mediated by PE. Being engaged implies that the individual is taking personal responsibility or playing the most important role in determining career progress. This involves taking charge of major career milestones, including the transition from being a student to a young professional. Engaged students are likely to engage in behaviors and activities that enhance their employability, for example by undertaking skills enhancement training. Moreover, engaged students are likely to be more active during learning processes consequently enhancing learning interest and competence (Raettig 2018). However, our results support the idea of focusing on specific aspects of PE; particularly along the internal and external facets (Rothwell et al. 2008; Rothwell and Arnold 2007). The patterns of effects of these facets on career outcomes tend to differ. In the present study, we found that internal PE was strongly associated with the readiness for STWT but not related to career satisfaction. On the other hand, the external facet was positively associated with career satisfaction, but negatively to the readiness for STWT. Moreover, our findings further indicate that external PE has a positive impact on internal PE.

These findings indicate that the university brand and the popularity of the subject studies contribute to one's efficacy to succeed in the labor market. Hence, external employability boosts the psychological resources for adjusting to STWT. However, a stronger external PE implies that the student's university and subject area are highly valued by employers and employment conditions are seen as less dynamic (Huang 2014a, 2014b; Rothwell et al. 2008). Unfortunately, the career environment is increasingly dynamic; hence relying on these external factors for employability without translating them into psychological strength may hurt preparation for STWT. Having studied the bestselling subject in a prestigious university can be satisfying, but definitely no longer sufficient to guarantee a job in the contemporary competitive labor market. For students to feel ready to start the STWT process, internal PE is a required boosting factor. Our findings illustrate that this boost accrues from high psychological capital and career engagement. We further observe that for the paths that are shared between internal and external PE, the effect on STWT is continuously 
positive. However, for the paths that are not shared between both dimensions, the effect of external PE on STWT turns negative. This may imply that studying at a university that has better branding, also the knowledge, skills, and abilities (KSAs) that a student can develop might be much better such that the student also feels well prepared for STWT. However, if the perception of KSAs developed is less favorable, the student might feel less prepared for STWT despite studying at a well-appreciated university or pursuing a muchdemanded course.

\subsection{Limitations}

The study has some limitations that should be considered. First, the findings are based on subjective measures of the readiness for STWT and career satisfaction. Although the attention in the present study was towards readiness for STWT, which is subjective in nature; objective measures could be developed for future studies, for example, measuring the specific milestones individuals have achieved in handling the transition process. Second, the findings are based on cross-sectional data obtained through selfreport instruments. These two limitations are associated with social desirability biases (Miller 2012), hence we cannot rule out the risk of inflated relations among the constructs studied. The third limitation concerns the sample of the study. Our sample comprised only university students; it is probable though that different results might be obtained with different samples such as students in vocational and other tertiary learning institutions. However, the sample was drawn from four universities in Uganda and Kenya. This implies that our results can be applied to most university students in the East African region and the continent at large.

\section{Conclusion and Practical Implications}

The results of the present study have important implications for both theory and practice. First, the findings support the social cognitive model of career self-management (Lent and Brown 2013) in the application to career transitions. The model highlights the role of self-efficacy and outcome expectations (optimism) which are considered proximal determinants of adaptive career behaviors. Adjusting to the school-to-work transition process is one of the adaptive behaviors that foster career development. Our results indicate that cognitive resources together summed in the construct of psychological capital are essential in this process.

This is also important for practice, particularly for educators and counselors. Efforts are needed during the course of study at university as well as at other levels to facilitate the growth of students' psychological capital. It has been posited that positive psychological resources can be enhanced through specific learning interventions such as persuasion, mastery and vicarious experiences concerning goal setting; using positive reinforcements such as appreciation, recognition and positive feedback; and well-being focused interventions such as relationships, meditation, and exercises (Luthans et al. 2004; Luthans and Youssef-Morgan 2017). Developing students' psychological capital is essential for their career satisfaction and preparing for STWT. However, these are long-term results. Psychological capital is also a critical resource for immediate behaviors during school as, for example, engagement in both career and study, which may translate into better grades. Our 
study has also indicated that it is an antecedent for perceived employability. People seek university education for purposes of strengthening their employability. Employability is not just about hard professional skills but also soft cognitive and social skills. Enabling students to develop psychological capital is essential for building these skills that enhance both perceived and objective employability.

Beyond student engagement, i.e. the engagement in learning activities, our study has highlighted the importance of career engagement among students. This has implications for educators, counselors, but even more critically for young people and their parents. There exist several influences on careers and career expectations of children including parents, friends, counselors, teachers, the school, contexts, and personal factors (e.g., Paa and McWhirter 2000; Whiston and Keller 2004). However, our study indicates that being engaged in one's career development process is essential for students to be satisfied with their career progress and to self-determinedly prepare for their career life beyond the school context. This kind of engagement implies that children or students are given the opportunity to take the central role in making decisions about their career, in involvement in planning their career, and enabling them to explore career opportunities (Hirschi 2010). Given that engagement is further related to the development of efficacy and other positive cognitive resources, it could also be considered an important proximal antecedent of adaptive career behaviors; therefore, it is necessary for career self-management.

In addition, our study supports Rothwell et al. (2008) and Huang (2014a, 2014b)'s efforts to segregate the effects of the different dimensions of PE, since each is likely to lead to a different outcome from the other. Our results suggest that educators and counselors should seek to enhance students' internal PE when they need to adjust to school-to-work transitions. This implies that explicitly enabling students realizing their competences is essential for transition activities such as job search and obtaining employment. On the other hand, they should strengthen students' external PE where the goal is to achieve career satisfaction, implying that students will get more career satisfaction from the realization that their training backgrounds are relevant to the labor market and that the labor market is most likely to provide them with job opportunities. Although this is not directly related to the readiness for STWT, it does improve internal PE, which in turn may lead to increased readiness for STWT as well.

Funding Information Open Access funding provided by Projekt DEAL.

\section{Compliance with Ethical Standards}

Conflict of Interest The authors declare no conflict of interest.

Open Access This article is licensed under a Creative Commons Attribution 4.0 International License, which permits use, sharing, adaptation, distribution and reproduction in any medium or format, as long as you give appropriate credit to the original author(s) and the source, provide a link to the Creative Commons licence, and indicate if changes were made. The images or other third party material in this article are included in the article's Creative Commons licence, unless indicated otherwise in a credit line to the material. If material is not included in the article's Creative Commons licence and your intended use is not permitted by statutory regulation or exceeds the permitted use, you will need to obtain permission directly from the copyright holder. To view a copy of this licence, visit http://creativecommons.org/licenses/by/4.0/. 


\section{References}

Abel, J. R., Deitz, R., \& Su, Y. (2014). Are recent college graduates finding good jobs? Current Issues in Economics and Finance, 20(1), 1-8 https://papers.ssrn.com/sol3/papers.cfm?abstract_id=2378472.

Akkermans, J., Nykänen, M., \& Vuori, J. (2015). Practice makes perfect? Antecedents and consequences of an adaptive school-to-work transition. In J. Vuori, R. Blonk, \& R. H. Price (Eds.), Sustainable Working Lives (pp. 65-86). Springer Netherlands. https://doi.org/10.1007/978-94-017-9798-6_5.

Arthur, M. B., Khapova, S. N., \& Wilderom, C. P. M. (2005). Career success in a boundaryless career world. Journal of Organizational Behavior, 26(2), 177-202. https://doi.org/10.1002/job.290.

Avey, J. B., Reichard, R. J., Luthans, F., \& Mhatre, K. H. (2011). Meta-analysis of the impact of positive psychological capital on employee attitudes, behaviors, and performance. Human Resource Development Quarterly, 22(2), 127-152. https://doi.org/10.1002/hrdq.20070.

Awiti, A. O., \& Scott, B. (2016). The Kenya youth survey report (pp. 1-4). East Africa Institute http://www. aku.edu/eai/Documents/kenya-youth-survey-report-executive-summary-2016.pdf.

Axelson, R. D., \& Flick, A. (2010). Defining student engagement. Change: The Magazine of Higher Learning, 43(1), 38-43. https://doi.org/10.1080/00091383.2011.533096.

Baay, P. E., Van Aken, M. A. G., De Ridder, D. T. D., \& Van der Lippe, T. (2014). Understanding the role of social capital in adolescents' big five personality effects on school-to-work transitions. Journal of Adolescence, 37(5), 739-748. https://doi.org/10.1016/j.adolescence.2014.04.015.

Bakker, A. B., \& Schaufeli, W. B. (2014). Work engagement. In A. B. Baker \& M. P. Leiter (Eds.), Work (issue 2008, pp. 1-7). Psychology press. https://doi.org/10.4324/9780203853047.

Bakker, A. B. I., Leiter, M. P., Leiter, \& Michael, P. (2009). Work Engagement: A Handbook of Essential Theory and Research (Vol. 5). Psychology Press. https://doi.org/10.1111/j.1744-6570.2011.01242_2.x.

Baluku, M. M., Kikooma, J. F., \& Otto, K. (2018). Positive mindset and entrepreneurial outcomes: The magical contributions of psychological resources and autonomy. Journal of Small Business and Entrepreneurship, 30(6), 473-498. https://doi.org/10.1080/08276331.2018.1459017.

Bandura, A. (1995). Exercise of personal and collective efficacy in changing societies. In A. Bandura (Ed.), Self-efficacy in changing societies. (Vol. 15, pp. 1-45). Cambridge University Press. https://doi. org/10.1017/cbo9780511527692.003.

Baron, R. A., Franklin, R. J., \& Hmieleski, K. M. (2016). Why entrepreneurs often experience low, not high, levels of stress: The joint effects of selection and psychological capital. Journal of Management, 42(3), 742-768. https://doi.org/10.1177/0149206313495411.

Berntson, E., \& Marklund, S. (2007). The relationship between perceived employability and subsequent health. Work and Stress, 21(3), 279-292. https://doi.org/10.1080/02678370701659215.

Blustein, D. L., Chaves, A. P., Diemer, M. a., Gallagher, L. a., Marshall, K. G., Sirin, S., \& Bhati, K. S. (2002). Voices of the forgotten half: The role of social class in the school-to-work transition. Journal of Counseling Psychology, 49(3), 311-323. https://doi.org/10.1037/0022-0167.49.3.311.

Brandt, T., Gomes, J. F. S., \& Boyanova, D. (2011). Personality and psychological capital as indicators of future job success? A multicultural comparison between three European countries. Finnish Journal of Business Economics, 3(11), 263-289 http://ta.hse.fi/2011/3/lta_2011_03_a1.pdf.

Caraway, K., Tucker, C. M., Reinke, W. M., \& Hall, C. (2003). Self-efficacy, goal orientation, and fear of failure as predictors of school engagement in high school students. Psychology in the Schools, 40(4), 417427. https://doi.org/10.1002/pits.10092.

Carver, C. S., Scheier, M. F., \& Segerstrom, S. C. (2010). Optimism. Clinical Psychology Review, 30(7), 879889. https://doi.org/10.1016/j.cpr.2010.01.006.

Chen, D. J. Q., \& Lim, V. K. G. (2012). Strength in adversity: The influence of psychological capital on job search. Journal of Organizational Behavior, 33(6), 811-839. https://doi.org/10.1002/job.1814.

Clarke, M. (2017). Rethinking graduate employability: The role of capital, individual attributes and context. Studies in Higher Education, 1-15. https://doi.org/10.1080/03075079.2017.1294152.

Coetzee, M., \& Schreuder, D. (2017). Proactive career self-management: Exploring links among psychosocial career attributes and adaptability resources. South Africa Journal of Psychology, 008124631771964. https://doi.org/10.1177/0081246317719646.

Cuyper, D., Nele, V. d. B., Anja, \& De Witte, H. (2015). Perceived employability in times of job insecurity: A theoretical perspective. In A. De Vos \& B. I. J. M. Van der Heijden (Eds.), Handbook of Research on Sustainable Careers (pp. 161-189). Edward Elgar Publishing.

Dacre Pool, L., \& Qualter, P. (2013). Emotional self-efficacy, graduate employability, and career satisfaction: Testing the associations. Australian Journal of Psychology, 65(4), 214-223. https://doi.org/10.1111 /ajpy.12023. 
Dall'erba, S., Percoco, M., \& Piras, G. (2009). Service industry and cumulative growth in the regions of Europe. Entrepreneurship and Regional Development, 21(4), 333-349. https://doi.org/10.1080 $/ 08985620903019815$.

Datu, J. A. D., King, R. B., \& Valdez, J. P. M. (2016). Psychological capital bolsters motivation, engagement, and achievement: Cross-sectional and longitudinal studies. The Journal of Positive Psychology, October, 1-11. https://doi.org/10.1080/17439760.2016.1257056.

De Vos, A., \& Soens, N. (2008). Protean attitude and career success: The mediating role of self-management. Journal of Vocational Behavior, 73(3), 449-456. https://doi.org/10.1016/j.jvb.2008.08.007.

De Vos, A., De Hauw, S., \& Van der Heijden, B. I. J. M. (2011). Competency development and career success: The mediating role of employability. Journal of Vocational Behavior, 79(2), 438-447. https://doi.org/10.1016/j.jvb.2011.05.010.

Dietrich, H., \& Möller, J. (2016). Youth unemployment in Europe - Business cycle and institutional effects. IEEP, 13(1), 5-25. https://doi.org/10.1007/s10368-015-0331-1.

Donald, W. E., Baruch, Y., \& Ashleigh, M. (2017). The undergraduate self-perception of employability: Human capital, careers advice, and career ownership. Studies in Higher Education, 1-16. https://oi. org/10.1080/03075079.2017.1387107.

Ford, P. R., Ward, P., Hodges, N. J., \& Williams, A. M. (2009). The role of deliberate practice and play in career progression in sport: The early engagement hypothesis. High Ability Studies, 20(1), 65-75. https://doi.org/10.1080/13598130902860721.

Forrier, A., \& Sels, L. (2003). The concept employability: a complex mosaic. International Journal of Human Resources Development and Management, 3(2), 102. https://doi.org/10.1504/IJHRDM.2003.002414.

Forrier, A., Verbruggen, M., \& De Cuyper, N. (2015). Integrating different notions of employability in a dynamic chain: The relationship between job transitions, movement capital and perceived employability. Journal of Vocational Behavior, 89, 56-64. https://doi.org/10.1016/j.jvb.2015.04.007.

Forstenlechner, I., Selim, H., Baruch, Y., \& Madi, M. (2014). Career exploration and perceived employability within an emerging economy context. Human Resource Management, 53(1), 45-66. https://doi. org/10.1002/hrm.21553.

Fredricks, J. A., Filsecker, M., \& Lawson, M. A. (2016). Student engagement, context, and adjustment: Addressing definitional, measurement, and methodological issues. Learning and Instruction, 43, 1-4. https://doi.org/10.1016/j.learninstruc.2016.02.002.

Fugate, M., Kinicki, A. J., \& Ashforth, B. E. (2004). Employability: A psycho-social construct, its dimensions, and applications. Journal of Vocational Behavior, 65(1), 14-38. https://doi.org/10.1016/j. jvb.2003.10.005.

Gerland, P., Raftery, A. E., ev ikova, H., Li, N., Gu, D., Spoorenberg, T., Alkema, L., Fosdick, B. K., Chunn, J., Lalic, N., Bay, G., Buettner, T., Heilig, G. K., \& Wilmoth, J. (2014). World population stabilization unlikely this century. Science, 346(6206), 234-237. https://doi.org/10.1126/science.1257469.

Gohmann, S. F., Hobbs, B. K., \& Mccrickard, M. (2008). Economic freedom and service industry growth in the United States. Entrepreneurship Theory and Practice, 32(5), 855-874. https://doi.org/10.1111/j.15406520.2008.00259.x.

Goldsmith, A. H., Veum, J. R., \& Darity, W. (1997). The impact of psychological and human capital on wages. Economic Inquiry, 35, 815-829. https://doi.org/10.1111/j.1465-7295.1997.tb01966.x.

Greenhaus, J. H., Parasuraman, S., \& Wormley, W. M. (1990). Effects of race on organizational experience, job performance evaluations, and career outcomes. The Academy of Management Journal, 33(1), 64-86. https://doi.org/10.2307/256352.

Guan, Y., Deng, H., Sun, J., Wang, Y., Cai, Z., Ye, L., Fu, R., Wang, Y., Zhang, S., \& Li, Y. (2013). Career adaptability, job search self-efficacy and outcomes: A three-wave investigation among Chinese university graduates. Journal of Vocational Behavior, 83(3), 561-570. https://doi.org/10.1016/j.jvb.2013.09.003.

Guan, M., Capezio, A., Restubog, S. L. D., Read, S., Lajom, J. A. L., \& Li, M. (2016). The role of traditionality in the relationships among parental support, career decision-making self-efficacy and career adaptability. Journal of Vocational Behavior, 94, 114-123. https://doi.org/10.1016/j.jvb.2016.02.018.

Hall, D. T. (1996). Careers of the 21st century. The Academy of Management Executive, 10(4), 8-16. https://doi.org/10.5465/AME.1996.3145315.

Hall, D. T. (2002). Careers In and Out of Organisations (foundation). Inc: SAGE Publications.

Hanapi, Z., \& Nordin, M. S. (2014). Unemployment among Malaysia graduates: graduates'attributes, lecturers' competency and quality of education. Procedia - Social and Behavioral Sciences, 112, 10561063. https://doi.org/10.1016/j.sbspro.2014.01.1269.

Hayes, A. F. (2012). PROCESS: A versatile computational tool for observed variable moderation, mediation, and conditional process modeling. In Manuscript submitted for publication (Issue January, pp. 1-39). http://www.afhayes.com/public/process2012.pdf 
Hayes, A. F. (2013). Introduction to mediation, moderation, and conditional process analysis (first edi). New York: Guilford Press.

Hayes, A. F. (2018). Introduction to mediation, moderation, and conditional process analysis: a regession approach (second edi). The Guilford Press.

Heckhausen, J., Chang, E. S., Greenberger, E., \& Chen, C. (2013). Striving for educational and career goals during the transition after high school: What is beneficial? Journal of Youth and Adolescence, 42(9), 1385-1398. https://doi.org/10.1007/s10964-012-9812-5.

Heppner, M. J. (1998). The career transitions inventory: Measuring internal resources in adulthood. Journal of Career Assessment, 6(2), 135-145. https://doi.org/10.1177/106907279800600202.

Heppner, M. J., Multon, K. D., \& Johnston, J. A. (1994). Assessing psychological resources during career change: Development of the career transitions inventory. Journal of Vocational Behavior, 44(1), 55-74. https://doi.org/10.1006/jvbe.1994.1004.

Heslin, P. A. (2005). Conceptualizing and evaluating career success. Journal of Organizational Behavior, 26(2), 113-136. https://doi.org/10.1002/job.270.

Hirschi, A. (2010). The role of chance events in the school-to-work transition: The influence of demographic, personality and career development variables. Journal of Vocational Behavior, 77(1), 39-49. https://doi. org/10.1016/j.jvb.2010.02.002.

Hirschi, A. (2014). Hope as a resource for self-directed career management: Investigating mediating effects on proactive career behaviors and life and job satisfaction. Journal of Happiness Studies, 15(6), 1495-1512. https://doi.org/10.1007/s10902-013-9488-x.

Hirschi, A., \& Jaensch, V. K. (2015). Narcissism and career success: Occupational self-efficacy and career engagement as mediators. Personality \& Individual Differences, 77, 205-208. https://doi.org/10.1016/j. paid.2015.01.002.

Hirschi, A., Niles, S. G., \& Akos, P. (2011). Engagement in adolescent career preparation: Social support, personality and the development of choice decidedness and congruence. Journal of Adolescence, 34(1), 173-182. https://doi.org/10.1016/j.adolescence.2009.12.009.

Hirschi, A., Lee, B., Porfeli, E. J., \& Vondracek, F. W. (2013). Proactive motivation and engagement in career behaviors: Investigating direct, mediated, and moderated effects. Journal of Vocational Behavior, 83(1), 31-40. https://doi.org/10.1016/j.jvb.2013.02.003.

Hirschi, A., Freund, P. A., \& Herrmann, A. (2014). The career engagement scale. Journal of Career Assessment, 22(4), 575-594. https://doi.org/10.1177/1069072713514813.

Hollenbeck, J. R., \& Mannor, M. J. (2007). Career success and weak paradigms: The role of activity, resiliency, and true scores. Journal of Organizational Behavior, 28(8), 933-942. https://doi.org/10.1002 /job.491.

Huang, H. C. (2014a). Entrepreneurial resources and speed of entrepreneurial success in an emerging market: The moderating effect of entrepreneurship. International Entrepreneurship and Management Journal, 415. https://doi.org/10.1007/s11365-014-0321-8.

Huang, J.-T. (2014b). Hardiness, perceived employability, and career decision self-efficacy among taiwanese college students. Journal of Career Development, 1-14. https://doi.org/10.1177/0894845314562960.

Inkson, K. (2006). Protean and boundaryless careers as metaphors. Journal of Vocational Behavior, 69(1), 4863. https://doi.org/10.1016/j.jvb.2005.09.004.

Jackson, D., \& Wilton, N. (2017). Perceived employability among undergraduates and the importance of career self-management, work experience and individual characteristics. Higher Education Research and Development, 36(4), 747-762. https://doi.org/10.1080/07294360.2016.1229270.

Kahu, E. R., \& Nelson, K. (2017). Student engagement in the educational interface: Understanding the mechanisms of student success. Higher Education Research and Development, 1-14. https://doi. org/10.1080/07294360.2017.1344197.

Kasler, J., Zysberg, L., \& Harel, N. (2017). Hopes for the future: Demographic and personal resources associated with self-perceived employability and actual employment among senior year students. Journal of Education and Work, 30(8), 1-12. https://doi.org/10.1080/13639080.2017.1352083.

Khan, N., \& Faisal, S. (2020). Epidemiology of corona virus in the world and its effects on the China economy. SSRN Electronic Journal. https://doi.org/10.2139/ssm.3548292.

Kim, B., Jang, S. H., Jung, S. H., Lee, B. H., Puig, A., \& Lee, S. M. (2014). A moderated mediation model of planned happenstance skills, career engagement, career decision self-efficacy, and career decision certainty. Career Development Quarterly, 62(1), 56-69. https://doi.org/10.1002/j.21610045.2014.00070.x

Kirves, K., Kinnunen, U., De Cuyper, N., \& Mäkikangas, A. (2014). Trajectories of perceived employability and their associations with well-being at work: A three-wave study. Journal of Personnel Psychology, 13(1 a), 46-57. https://doi.org/10.1027/1866-5888/a000103. 
Koen, J., Klehe, U. C., \& Van Vianen, A. E. M. (2012). Training career adaptability to facilitate a successful school-to-work transition. Journal of Vocational Behavior, 81(3), 395-408. https://doi.org/10.1016/j. jvb.2012.10.003.

Konstam, V. (2015). Floundering or experimenting: Finding a vocational home. In Emerging and Young Adulthood. Advancing Responsible Adolescent Development (pp. 95-113). Cham: Springer. https://doi. org/10.1007/978-3-319-11301-2_7.

Körner, A., Lechner, C. M., Pavlova, M. K., \& Silbereisen, R. K. (2015). Goal engagement in coping with occupational uncertainty predicts favorable career-related outcomes. Journal of Vocational Behavior, 88, 174-184. https://doi.org/10.1016/j.jvb.2015.03.001.

Krahn, H. J., Howard, A. L., \& Galambos, N. L. (2015). Exploring or floundering? The meaning of employment and educational fluctuations in emerging adulthood. Youth Society, 47(2), 245-266. https://doi.org/10.1177/0044118X12459061.

Krumboltz, J. D., \& Worthington, R. L. (1999). The school-to-work transition from a learning theory perspective. Career Development Quarterly, 47(4), 312. https://doi.org/10.1002/j.2161-0045.1999. tb00740.x.

Le, H., Jiang, Z., \& Nielsen, I. (2016). Cognitive cultural intelligence and life satisfaction of migrant workers: The roles of career engagement and social injustice. Social Indicators Research, 1-21. https://doi. org/10.1007/s11205-016-1393-3.

Lent, R. W., \& Brown, S. D. (2013). Social cognitive model of career self-management: Toward a unifying view of adaptive career behavior across the life span. Journal of Counseling Psychology, 60(4), 557-568. https://doi.org/10.1037/a0033446.

Lent, R. W., Brown, S. D., \& Hackett, G. (1994). Toward a unifying social cognitive theory of career and academic interest, choice, and performance. Journal of Vocational Behavior, 45(1), 79-122. https://doi. org/10.1006/jvbe.1994.1027.

Lent, R. W., Miller, M. J., Smith, P. E., Watford, B. A., Lim, R. H., Hui, K., Morrison, M. A., Wilkins, G., \& Williams, K. (2013). Social cognitive predictors of adjustment to engineering majors across gender and race/ethnicity. Journal of Vocational Behavior, 83(1), 22-30. https://doi.org/10.1016/j.jvb.2013.02.006.

Lent, R. W., Ezeofor, I., Morrison, M. A., Penn, L. T., \& Ireland, G. W. (2016). Applying the social cognitive model of career self-management to career exploration and decision-making. Journal of Vocational Behavior, 93, 47-57. https://doi.org/10.1016/j.jvb.2015.12.007.

Lim, R. H., Lent, R. W., \& Penn, L. T. (2016). Prediction of job search intentions and behaviors: Testing the social cognitive model of career self-management. Journal of Counseling Psychology, 63(5), 594-603. https://doi.org/10.1037/cou0000154.

Ling, T. J., \& O'Brien, K. M. (2013). Connecting the forgotten half: The school-to-work transition of noncollege-bound youth. Journal of Career Development, 40(4), 347-367. https://doi.org/10.1177 /0894845312455506.

Lo Presti, A., \& Pluviano, S. (2015). Looking for a route in turbulent waters: Employability as a compass for career success. Organizational Psychology Review, May, 1-20. https://doi.org/10.1177 $/ 2041386615589398$.

Luthans, F. (2012). Psychological capital: Implications for HRD, retrospective analysis, and future directions. Human Resource Development Quarterly, 23(1), 1-8. https://doi.org/10.1002/hrdq.21119.

Luthans, F., \& Avolio, B. J. (2014). Brief summary of psychological capital and introduction to the special issue. Journal of Leadership and Organizational Studies, 21(2), 125-129. https://doi.org/10.1177 $/ 1548051813518073$.

Luthans, F., \& Jensen, S. M. (2002). Hope: A new positive strength for human resource development. Human Resource Development Review, 1(3), 304-322. https://doi.org/10.1177/1534484302013003.

Luthans, F., \& Youssef-Morgan, C. M. (2017). Psychological capital: An evidence-based positive approach. Annual Review of Organizational Psychology and Organizational Behavior, 4(1), 339-366. https://doi. org/10.1146/annurev-orgpsych-032516-113324.

Luthans, F., Luthans, K. W., \& Luthans, B. C. (2004). Positive psychological capital: Beyond human and social capital. Business Horizons, 47(1), 45-50. https://doi.org/10.1016/j.bushor.2003.11.007.

Luthans, F., Avey, J. B., Avolio, B. J., Norman, S. M., \& Combs, G. M. (2006a). Psychological capital development: Toward a micro-intervention. Journal of Organizational Behavior, 27(3), 387-393. https://doi.org/10.1002/job.373.

Luthans, F., Vogelgesang, G. R., \& Lester, P. B. (2006b). Developing the psychological capital of resiliency. Human Resource Development Review, 5(1), 25-44. https://doi.org/10.1177/1534484305285335.

Luthans, F., Avolio, B. J., \& Avey, J. B. (2007a). Psychological capital (PsyCap) questionnaire (PCQ). Inc: Mind Garden. 
Luthans, F., Avolio, B. J., Avey, J. B., \& Norman, S. M. (2007b). Positive psychological capital: Measurement and relationship with performance and satisfaction. Personnel Psychology, 60(3), 541572. https://doi.org/10.1111/j.1744-6570.2007.00083.x.

Luthans, F., Avey, J. B., \& Patera, J. L. (2008). Experimental analysis of a web-based training intervention to develop positive psychological capital. Academy of Management Learning and Education, 7(2), 209221. https://doi.org/10.5465/AMLE.2008.32712618.

Luthans, B. C., Luthans, K. W., \& Avey, J. B. (2014). Building the leaders of tomorrow. Journal of Leadership \& Organizational Studies, 21(2), 191-199. https://doi.org/10.1177/1548051813517003.

Luthans, F., Youssef, C. M., \& Avolio, B. J. (2015). Psychological capital and beyond. Oxford University Press. https://doi.org/10.1002/smi.2623.

Masten, S. A., \& Reed, M. J. (2002). Resilience in development. In C. R. Snyder \& S. J. López (Eds.), Handbook of positive psychology (pp. 74-88). New York: Oxford University press.

Masten, A. S., Burt, K. B., Roisman, G. I., Obradović, J., Long, J. D., \& Tellegen, A. (2004). Resources and resilience in the transition to adulthood: Continuity and change. Development and Psychopathology, 16(4), 1071-1094. https://doi.org/10.1017/S0954579404040143.

Miller, A. (2012). Investigating social desirability bias in student self-report surveys. Association for Institutional Research, 36(1), 30-47.

Morton, S., Mergler, A., \& Boman, P. (2014). Managing the transition: The role of optimism and self-efficacy for first-year australian university students. Australian Journal of Guidance and Counselling, 24(01), 90108. https://doi.org/10.1017/jgc.2013.29.

Munoz, R. T., Hellman, C. M., Buster, B., Robbins, A., Carroll, C., Kabbani, M., Cassody, L., Brahm, N., \& Fox, M. D. (2016). Life satisfaction, hope, and positive emotions as antecedents of health related quality of life among homeless individuals. International Journal of Applied Positive Psychology, 1(1-3), 69-89. https://doi.org/10.1007/s41042-017-0005-z.

Nathan, A. J., \& Scobell, A. (2012). How China sees America. In Foreign Affairs (Vol. 91, issue 5). https://doi. org/10.1017/CBO9781107415324.004.

Neault, R. A., \& Pickerell, D. A. (2011). Career engagement: Bridging career counseling and employee engagement. Journal of Employment Counseling, 48(4), 185-188. https://doi.org/10.1002/j.21611920.2011.tb01111.x.

Newman, A., Ucbasaran, D., Zhu, F., \& Hirst, G. (2014). Psychological capital: A review and synthesis. Journal of Organizational Behavior, 35(SUPPL.1), S120-S138. https://doi.org/10.1002/job.1916.

Nunnally, J. C. J. (1978). Psychometric theory. Auflage, New York Ua: Mc Graw-Hill.

Paa, H. K., \& McWhirter, E. H. (2000). Perceived influences on high school students' current career expectations. Career Development Quarterly, 49(1), 29-44. https://doi.org/10.1002/j.2161-0045.2000. tb00749.x.

Page, L. F., \& Donohue, R. (2004). Positive psychological capital : a preliminary exploration of the construct. Monash University Department of Management Working Paper Series (Vol. 51/04, pp. 1-10) https://pdfs.semanticscholar.org/be41/bf19e03d4c6eeae3de7f46e39f5282fe1e03.pdf.

Pastore, F. (2015). The Youth Experience Gap Explaining National Differences in the School-to-Work Transition. Springer. https://doi.org/10.1007/978-3-319-10196-5.

Perera, H. N., \& McIlveen, P. (2014). The role of optimism and engagement coping in college adaptation: A career construction model. Journal of Vocational Behavior, 84(3), 395-404. https://doi.org/10.1016/j. jvb.2014.03.002.

Peterson, C. (2000). The future of optimism. The American Psychologist, 55(1), 44-55. https://doi. org/10.1037//0003-066X.55.1.44.

Pinquart, M., Juang, L. P., \& Silbereisen, R. K. (2003). Self-efficacy and successful school-to-work transition: A longitudinal study. Journal of Vocational Behavior, 63(3), 329-346. https://doi.org/10.1016/S00018791(02)00031-3.

Praskova, A., Creed, P. a., \& Hood, M. (2014). Self-regulatory processes mediating between career calling and perceived employability and life satisfaction in emerging adults. Journal of Career Development, 42(2), 86-101. https://doi.org/10.1177/0894845314541517.

Quintini, G., \& Martin, S. (2014). Same but different: School-to-work transitions in emerging and advanced economies. In OECD Social, Employment and Migration Working Papers: Vol. No. 154 (154, pp. 1-57). OECD publishing. https://doi.org/10.1787/5jzbb2t1rcwc-en.

Raettig, T. (2018). Learning as a shared peak experience: Interactive flow in higher education. International Journal of Applied Positive Psychology, 1-22. https://doi.org/10.1007/s41042-018-0011-9

Reeskens, T., \& Oorschot, W. V. (2012). Those who are in the gutter look at the stars? Explaining perceptions of labour market opportunities among European young adults. Work, Employment \& Society, 26(3), 379 395. https://doi.org/10.1177/0950017012438575. 
Rothwell, A., \& Arnold, J. (2007). Self-perceived employability: Development and validation of a scale. Personnel Review, 36(1), 23-41. https://doi.org/10.1108/00483480710716704.

Rothwell, A., Herbert, I., \& Rothwell, F. (2008). Self-perceived employability: Construction and initial validation of a scale for university students. Journal of Vocational Behavior, 73(1), 1-12. https://doi. org/10.1016/j.jvb.2007.12.001.

Rothwell, A., Jewell, S., \& Hardie, M. (2009). Self-perceived employability: Investigating the responses of post-graduate students. Journal of Vocational Behavior, 75(2), 152-161. https://doi.org/10.1016/j. jvb.2009.05.002.

Ruiz Estrada, M. A., Park, D., Koutronas, E., Khan, A., \& Tahir, M. (2020). The impact of infectious and contagious diseases and its impact on the economic performance: The case of Wuhan, China SSRN. Electronic Journal. https://doi.org/10.2139/ssrn.3527330.

Ryan, P. (2001). The school-to-work transition: a cross-national perspective. Journal of Economic Literature http://www.jstor.org/stable/2698454.

Salmela-Aro, K., \& Upadaya, K. (2012). The schoolwork engagement inventory: Energy, dedication, and absorption (EDA). European Journal of Psychological Assessment, 28(1), 60-67. https://doi.org/10.1027 /1015-5759/a000091.

Schaufeli, W. B., \& Bakker, A. B. (2000). Defining and measuring work engagement: Bringing clarity to the concept. In A. B. Baker \& M. P. Leiter (Eds.), Work (pp. 10-24). Psychology press. https://doi. org/10.4324/9780203853047.

Sharland, A., Mitchell, D., \& Menon, M. (2013). An international comparison of school to work transition systems: How best to evaluate outcomes. International Journal of Society Systems Science, 5(2), 99. https://doi.org/10.1504/IJSSS.2013.053749.

Simons, J. H., \& Buitendach, J. H. (2013). Psychological capital, work engagement and organisational commitment amongst call Centre employees in South Africa. SA Journal of Industrial Psychology, 39(2), 1-12. https://doi.org/10.4102/sajip.v39i2.1071.

Smidt, W., Kammermeyer, G., Roux, S., Theisen, C., \& Weber, C. (2017). Career success of preschool teachers in Germany - The significance of the big five personality traits, locus of control, and occupational self-efficacy. Early Child Development and Care, 1-14. https://doi.org/10.1080 /03004430.2017.1314275.

Snyder, C. R. (2002). Hope theory: Rainbows in the mind. Psychological Inquiry, 13(4), 249-275. https://doi. org/10.1207/S15327965PLI1304_01.

Snyder, C. R., Sympson, S. C., Ybasco, F. C., Borders, T. F., Babyak, M. A., \& Higgins, R. L. (1996). Development and validation of the state hope scale. Journal of Personality and Social Psychology, 70(2), 321-335. https://doi.org/10.1037/0022-3514.70.2.321.

Sortheix, F. M., Chow, A., \& Salmela-Aro, K. (2015). Work values and the transition to work life: A longitudinal study. Journal of Vocational Behavior, 89, 162-171. https://doi.org/10.1016/j. jvb.2015.06.001.

Spurk, D., Kauffeld, S., Barthauer, L., \& Heinemann, N. S. R. (2015). Fostering networking behavior, career planning and optimism, and subjective career success: An intervention study. Journal of Vocational Behavior, 87, 134-144. https://doi.org/10.1016/j.jvb.2014.12.007.

Sturges, J. (1999). What it means to succeed: Personal conceptions of career success held by male and female managers at different ages. British Journal of Management, 10(3), 239-252. https://doi.org/10.1111 /1467-8551.00130.

Sulemana, I., Nketiah-Amponsah, E., Codjoe, E. A., \& Andoh, J. A. N. (2019). Urbanization and income inequality in sub-Saharan Africa. Sustainable Cities and Society, 48, 101544. https://doi.org/10.1016/j. scs.2019.101544.

Tomasik, M. J., Hardy, S., Haase, C. M., \& Heckhausen, J. (2009). Adaptive adjustment of vocational aspirations among German youths during the transition from school to work. Journal of Vocational Behavior, 74(1), 38-46. https://doi.org/10.1016/j.jvb.2008.10.003.

Trevelyan, R. (2008). Optimism, overconfidence and entrepreneurial activity. Management Decision, 46(7), 986-1001. https://doi.org/10.1108/00251740810890177.

Upadyaya, K., \& Salmela-Aro, K. (2015). Development of early vocational behavior: Parallel associations between career engagement and satisfaction. Journal of Vocational Behavior, 90, 66-74. https://doi. org/10.1016/j.jvb.2015.07.008.

Valero, D., Hirschi, A., \& Strauss, K. (2015). Hope in adolescent careers: Mediating effects of work motivation on career outcomes in swiss apprentices. Journal of Career Development, 42(5), 381-395. https://doi.org/10.1177/0894845314566866. 
Van Der Heijde, C. M., \& Van Der Heijden, B. I. J. M. (2006). A competence-based and multidimensional operationalization and measurement of employability. Human Resource Management, 45(3), 449-476. https://doi.org/10.1002/hrm.20119.

Vanhercke, D., De Cuyper, N., Peeters, E., \& De Witte, H. (2014). Defining perceived employability: a psychological approach. Personnel Review, 43(4), 592-605. https://doi.org/10.1108/PR-07-2012-0110.

Vardaman, J. M., Amis, J. M., Dyson, B. P., Wright, P. M., \& Van de Graaff Randolph, R. (2012). Interpreting change as controllable: The role of network centrality and self-efficacy. Human Relations; Studies Towards the Integration of the Social Sciences, 65(7), 835-859. https://doi.org/10.1177 $/ 0018726712441642$.

Vuolo, M., Staff, J, \& Mortimer, J. T. (2011). Weathering the great recession: Psychological and behavioral trajectories in the transition from school to work. Developmental Psychology, 48(6), 1759-1773. https://oi.org/10.1037/a0026047.

Vuolo, M., Mortimer, J. T., \& Staff. J. (2014). Adolescent precursors of pathways from school to work. Journal of Research on Adolescence, 24(1), 145-162. https://doi.org/10.1111/jora.12038.

Weiss, F. (2014). From school to work and back-inequality in late postsecondary education as part of the school to work transition in the US, Germany and Sweden. XVIII ISA World Congress of Sociology (July 13-19, 2014).

Whiston, S. C., \& Keller, B. K. (2004). The influences of the family of origin on career development. The Counseling Psychologist, 32(4), 493-568. https://doi.org/10.1177/0011000004265660.

Wittekind, A., Raeder, S., \& Grote, G. (2010). A longitudinal study of determinants of perceived employability. Journal of Organizational Behavior, 31(4), 566-586. https://doi.org/10.1002/job.646.

Publisher's Note Springer Nature remains neutral with regard to jurisdictional claims in published maps and institutional affiliations.

\section{Affiliations}

\section{Martin Mabunda Baluku ${ }^{1,2}$. Eriphase Nsaale Mugabi ${ }^{1}$ - Joyce Nansamba ${ }^{1}$. Leonsio Matagi ${ }^{1} \cdot$ Peter Onderi $^{3} \cdot$ Kathleen Otto $^{2}$}

Eriphase Nsaale Mugabi

generousmugabi@yahoo.com

Joyce Nansamba

jnansamba21@gmail.com

Leonsio Matagi

matajileon@yahoo.com

Peter Onderi

peteronderi@gmail.com

Kathleen Otto

kathleen.otto@staff.uni-marburg.de

1 Department of Educational, Social, \& Organizational Psychology, Makerere University School of Psychology, P. O Box, 7062 Kampala, Uganda

2 Work and Organizational Psychology, Faculty of Psychology, Philipps-Universität, Gutenberg Str. 18, D-35032 Marburg, Germany

3 Department of Psychology, Maseno University, Private Bag, Maseno, Kenya 